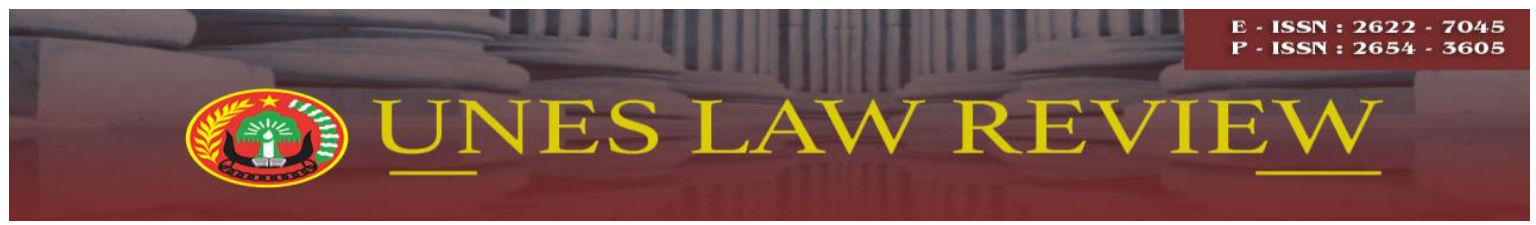

Email: uneslawreview@gmail.com

Online: http://review-unes.com/index.php/law

Volume 2, Issue 3, Maret 2020

\title{
UPAYA JAKSA SELAKU EKSEKUTOR DALAM EKSEKUSI PUTUSAN PIDANA TAMBAHAN PENGEMBALIAN KERUGIAN KEUANGAN NEGARA AKIBAT TINDAK PIDANA KORUPSI ( Studi Pada Kejaksaan Tinggi Sumatera Barat )
}

\author{
Hafri Sundhana \\ Kepolisian Daerah Sumatra Barat, Padang, Indonesia \\ Email : hafrisundhana@yahoo.co.id
}

\begin{abstract}
The Prosecutor as a position granted by the law to execute the decision of a judge who already has permanent legal force is regulated in Article 1 (one) Item 1 (one) of Law Number 16 Year 2004 concerning the Attorney General of the Republic of Indonesia. Although the Prosecutor has attempted to save state finances by taking a number of legal actions in the form of payment of an amount of replacement money, in reality the state financial losses have not been returned to the quantity that should be or can be said to have not even the slightest amount of state financial losses successfully returned by the Executing Prosecutor. The issues raised in this thesis are: First, how is the effort of the prosecutor as the executor in executing additional criminal decisions to recover state financial losses due to criminal acts of corruption at the West Sumatra High Prosecutor's Office? Second, whether the legal consequences of the execution of the Additional Criminal Decision refund of State Financial Losses that have not been successfully carried out by the Prosecutor's Executor. Data sources used are secondary data and primary data. The data obtained were analyzed qualitatively and presented in a descriptive qualitative form. Based on the results of the discussion and analysis, it can be concluded as follows: First, the efforts made by the Executing Prosecutor in returning state financial losses due to corruption, include: (1) Making Declaration of payment of replacement money; (2) Tracing assets back; Second, the legal consequences of the execution of additional criminal decisions were not successfully carried out by the Executing Prosecutor, among others: (1) Submitting the case to the Datun section (Civil and State Administration) carried out in a civil suit through the State Attorney Attorney, and; (2) To serve a subsidair sentence in accordance with the content of a judge's decision that has permanent legal force.
\end{abstract}

Kata Kunci: Pidana Korupsi, Eksekusi Putusan Pidana Tambahan, Pengembalian Kerugian Keuagan Negara

\section{PENDAHULUAN}

Persoalan pemberantasan korupsi di Indonesia bukan saja hanya persoalan hukum dan penegakan hukum semata-mata melainkan persoalan sosial dan psikologi sosial dan sungguh sangat parah dan sama parahnya dengan persoalan hukum, sehingga wajib 
dibenahi negara secara simultan. Korupsi juga merupakan persoalan sosial karena korupsi mengakibatkan tidak adanya pemerataan kesejahteraan dan merupakan persoalan psikologi karena korupsi merupakan penyakit sosial yang sulit untuk disembuhkan.

Pelaksanaan pengembalian kerugian keuangan negara akibat tindak pidana korupsi juga tidak serta merta dapat begitu saja dilakukan. Selain menunggu pembayaran uang pengganti dari para terpidana kasus korupsi yang memerlukan waktu yang lama, pengembalian uang pengganti ke kas negara tidak dapat langsung dilakukan. Hal ini diakibatkan adanya prosedur birokrasi yang dilewati,sehingga membutuhkan waktu untuk mengembalikan kerugian keuangan negara ke kas negara agar dapat segera digunakan untuk kesejahteraan rakyat.

Eksekusi pada dasarnya merupakan salah satu kewenangan jaksa yang diatur undangundang untuk melaksanakan putusan hakim. Putusan hakim yang dapat dilakukan eksekusi hanyalah putusan hakim yang sudah memperoleh kekuatan hukum tetap (inkrachtvan gewijsde). negara-negara Asean lainnya seperti Malaysia dan Filipina (Andi Hamzah, 2008). Denny Indrayana juga mengatakan bahwa Indonesia berada di posisi ke-5 sebagai negara terkorup di dunia Dari beberapa hal yangharus dilakukaneksekusi tersebut, yang menimbulkan persoalan adalah eksekusi terhadap pembayaran uang pengganti yang menjadike wajiban tambahan dari terpidana dalam perkara tindak pidana korupsi. Upaya Eksekusi terhadap perkara korupsi yang ditangani Kejaksaan Tinggi Sumatera Barat yang dilakukan terhadap uang pengganti,. Meskipun Jaksa telah berupaya untuk menyelamatkan keuangan negara dengan melakukan beberapa tindakan hukum berupa pembayaran sejumlah uang pengganti, namun pada kenyataannya kerugian keuangan negara tersebut belum dapat dikembalikan dengan kuantitas yang seharusnya atau dapat dikatakan belum ada sedikitpun kerugian keuangan negara tersebut yang berhasil dikembalikan oleh Jaksa Eksekutor.

Tindak pidana korupsi di Sumatera Barat seperti jamur yang sangat cepat pertumbuhannya. Pada tahun 2017-2018 ini saja ada sekitar 29 perkara tindak pidana korupsi yang sedang ditangani oleh Kejaksaan Tinggi Sumatera Barat dan Kejaksaan Negeri Seluruh Sumatera Barat (Amir Ilyas, 2012).

Berdasarkan Uraian diatas, saya tertarik untuk mdengetahi dan meng-analisis Upaya Jaksa Selaku Eksekutor Dalam Eksekusi Putusan Pidana Tambahan Pengembalian 
Kerugian Keuangan Negara Akibat Tindak Pidana Korupsi dan apakah akibat hukum terhadap eksekusi Putusan Pidana Tambahan pengembalian Kerugian Keuangan Negara yang tidak berhasil dilaksanakan Oleh Jaksa Eksektor.

\section{METODE PENELITIAN}

Untuk menjawab permasalahan dalam tesis ini dilakukan pendekatan yuridis normative yang didukung oleh pendekatan yuridis empiris dengan menggunakan data sekunder dan data primer yang diperoleh melalui studi kepustakaan dan hasil penelitian. Spesifikasi penelitian ini adalah deskriptif analitis yaitu untuk menggambarkan sekaligus menganalisis peraturan perundang-undangan dan teori-teori hukumyang berkaitan dengan permasalahan yang dibahas.

\section{HASIL PENELITIAN DAN PEMBAHASAN}

\section{Upaya Jaksa Selaku Eksekutor Dalam Eksekusi Putusan Pidana Tambahan Pengembalian Kerugian Keuangan Negara Akibat Tindak Pidana Korupsi Pada Kejaksaan Tinggi Sumatera Barat}

Penelitian ini ditujukan untuk meneliti kasus-kasus korupsi yang menimbulkan kerugian keuangan negara yang dihukum dengan pidana tambahan berupa pembayaran uang pengganti yang dimulai dari tahun 2017 (dua ribu enam belas) sampai dengan 2018 (dua ribu delapan belas) bulan Desember dan juga pelaksanaan hukuman (eksekusi) dari pada hukuman tersebut. Bukan hanya kuantitas dari pada kasus korupsi yang terjadi dalam rentan waktu tersebut saja, melainkan juga kuantitas dari proses eksekusi yang dilakukan dalam rentang waktu tersebut.

Ada 29 (dua puluh Sembilan) perkara korupsi yang ditangani oleh Kejaksaan Tinggi Sumatera Barat. jika dilihat perkara yang berhasil diputus dan telah memiliki kekuatan hukum tetap dari tahun 2017 sampai dengan tahun 2018 ada sebanyak 12 (dua belas) perkara. 8 Perkara pada 2017 dan Perkara pada 2018 dan 12 Perkara tersebut merupakan Tindak Pidana yang dikenakan Pidana tambahan Uang Pengganti

Sedangkan yang berhasil di eksekusi oleh jaksa eksekutor hanya 3 Perkara dalam kurun waktu tahun 2017 sampai tahun 2018 sedangkan ada 9 Perkara yang tidak bisa dikembalikan . 
Setelah putusan berkekuatan hukum tetap, untuk melakukan eksekusi ganti kerugian kepada negara, maka putusan dikirimkan kepada Kejaksaan Negeri sesuai wilayah hukumnya untuk dilaksanakan eksekusi, setalah itu Kejaksaan Negeri akan menerbitkan Surat Tagihan Denda/Uang Pengganti/biaya perkara (D-1), yang nantinya diserahkan kepada terpidana. Besarnya tagihan uang pengganti yang dibebankan untuk mengembalikan kerugian keuangan negara sesuai dengan hasil korupsi yang dilakukan, sesuai yang ditentukan oleh putusan hakim pengadilan. Setelah terbitnya D-1, maka Kejaksaan mengeluarkan Surat Pernyataan (D-2), yang pada intinya surat tersebut menyatakan kesanggupan atau tidak sanggup dari terpidana untuk membayar denda dan uang pengganti yang jumlahnya telah ditetapkan dalam putusan hakim pengadilan yang memiliki kekuatan hukum tetap.

Sesuai dengan peraturan perundang-undangan yang berlaku, uang pengganti harus dibayarkan maksimal satu bulan sejak putusan berkekuatan hukum tetap. Biasanya Jaksa yang melakukan eksekusi biasanya adalah Jaksa Penuntut Umum perkara tersebut. Ini karena suatu perkara dianggap tuntas bukan setelah adanya putusan pengadilan, namun ketika sudah dilaksanakan eksekusi, sehingga Jaksa Penuntut Umum dirasa masih memiliki tugas sampai eksekusinya dilaksanakan.

Hal ini berbeda dengan pengaturan di dalam Undang-Undang Nomor 3 Tahun 1971 tentang Pemberantasan Tindak Pidana Korupsi dimana terpidana tidak dapat mengganti pembayaran atau pelunasan pidana tambahan berupa uang pengganti dengan pidana penjara. Sehingga pembayaran uang pengganti terus dilakukan bahkan sampai ke ahli waris terpidana. Ini mengakibatkan bertumpuknya piutang yang dimiliki oleh Kejaksaan RI.

Berdasarkan hal ini pada tanggal 18 Januari 2013 Jaksa Agung mengeluarkan Surat Edaran Nomor B012/A/Cu.2/01/ 2013 perihal Pedoman Penyelesaian dan Kebijakan akuntansi atas Piutang Negara Uang Pengganti Perkara Tindak Pidana Korupsi dan Temuan Badan Pemeriksa Keuangan Republik Indonesaia atas laporan Keuangan Kejaksaan Republik Indonesia Tahun 2012 yang ditindak-lanjuti juga dengan mengeluarkan Peraturan Jaksa Agung RI Nomor: PER-020/A/JA/07/2014 tentang Petunjuk Pelaksanaan Penyelesaian Uang Pengganti yang diputus pengadilan berdasarkan UndangUndang Nomor 3 Tahun 1971 tentang pemberantasan Tindak Pidana Korupsi. 
Dimana pada intinya menghapus secara mutlak dari neraca sebagai piutang apabila telah dilakukan upaya pengembalian baik secara litigasi maupun non litigasi secara maksimal. Sehingga piutang yang dimiliki oleh Kejaksaan pasca dilakukan hal tersebut adalah piutang yang dimiliki oleh terpidana yang diputus dengan UU Tipikor yang baru.

Apabila terpidana bersedia membayar uang pengganti, maka langkah selanjutnya Kejaksaan akan menerbitkan kembali Tanda Terima Pembayaran Denda/Denda Ganti/Uang Pengganti/Biaya Perkara (D-3), surat ini merupakan sebagai bukti bahwa terpidana telah membayarkan uang pengganti kerugian keuangan negara yang dibayarkan melalui bendahara penerimaan Kejaksaan Negeri yang nantinya akan disetorkan atau dikembalikan kepada instansi yang dirugikan/Kas Negara akibat perbuatan korupsi yang telah dilakukan oleh terpidana.

Proses yang terakhir adalah dengan diterbitkannya Surat Perintah Penyerahan Denda/Denda Ganti/Uang Pengganti/ Biaya Perkara (D-4), dimana uang dari terpidana kasus korupsi ini diserahkan kepada Jaksa, yang kemudian akan diserahkan kembali kepada Bendahara Penerimaan Kejaksaan.

Pengembalian kerugian keuangan negara ini dikirimkan ke Kas Negara melalui rekening resmi Bank Rakyat Indonesia (BRI) milik Kas Negara apabila bersumber dari Anggaran Pendapatan dan Belanja Negara (APBN). Berbeda lagi bila yang dirugikan bersumber pada Anggaran Pendapatan Belanja Daerah (APBD), Badan Usaha Milik Negara (BUMN), Badan Usaha Milik Daerah (BUMD) dapat dikembalikan melalui Bank Pemerintah Daerah (BPD) pada setiap provinsi masing-masing, sedangkan apabila yang dirugikan adalah instansi yang berada di tingkat Kabupaten/Kota maka dapat dikembalikan melalui rekening resmi Pemerintah Kota/atau Pemerintah Kabupaten.

Namun bagaimana jika terpidana mengajukan Peninjauan Kembali? Berkaitan dengan Peninjauan Kembali, hal ini diatur dalam pasal 263 ayat (1) Kitab Undang-undang Hukum Acara Pidana (KUHAP) yang menyatakan bahwa terhadap putusan pengadilan yang telah mempunyai kekuatan hukum tetap, kecuali putusan bebas atau lepas dari tuntutan hukum, terpidana atau ahli warisnya dapat mengajukan permintaaan peninjauan kembali kepada Mahkamah Agung, dengan ketentuan bahwa peninjauan kembali tidak dapat menunda pelaksanaan eksekusi. 
Pada hakikatnya, uang pengganti adalah merupakan hutang terpidana kepada negara. Sehingga sewaktu-waktu dapat ditagih apabila tidak dibayarkan. Sehingga dalam pelaksanaannya tidak terbatas hanya dalam tempo satu bulan sejak putusan berkekuatan hukum tetap, namun tetap ditagih dan harus dibayarkan oleh terpidana selama masih menjalankan hukuman pidana pokok.

Dalam hal uang pengganti sudah didapatkan, maka yang dilakukan oleh Jaksa adalah menyerahkan uang tersebut kepada Bendahara Penerima dari Kejaksaan Negeri, dimana setelah itu Bendahara Penerima Kejaksaan Negeri dalam waktu 1 x 24 jam sejak diterima dari Jaksa Eksekutor wajib menyetorkan kepada negara melalui Surat Setoran Bebas Pajak (SSBP) dan keluar bukti pembayaran berupa (Nomor Tanda Penerimaan Negara (NTPN) sebagai bukti bahwa uang/pembayaran telah masuk negara.

Melihat fenomena tersebut tentu hal ini tidak sesuai dengan sifat hukum yang dipegang oleh Indonesia yaitu proaktif. Jaksa hanya bersifat menunggu tanpa melakukan suatu tindakan dalam upaya penyerahan surat pernyataan dan hanya menunggu inisiatif dari pihak terpidana. Seharusnya Jaksa lebih bersikap proaktif terhadap upaya penyerahan surat pernyataan ini dengan capaian agar terpidana dapat menyerahkan surat tersebut lebih cepat sehingga Jaksa dapat bekerja lebih efisien dalam menyelesaikan kasus ini dan dapat mengambil kebijakan untuk melakukan tindakan lanjutan.

Bukan hanya itu, alasan Jaksa Eksekutor tidak melakukan eksekusi dikarenakan pihak terdakwa belum menyerahkan surat keterangan yang berisikan kesanggupan atau ketidak-sanggupan terpidana dalam melakukan pembayaran uang pengganti merupakan tindakan yang keliru. Jaksa sebagai jabatan yang diberikan kewenangan dalam hal ini seharusnya tidak terpaku dengan surat tersebut. Hal ini mengingat surat pernyataan tersebut hanya merupakan suatu formalitas karena meskipun surat tersebut tidak diberikan kepada Jaksa oleh pihak terpidana Jaksa tetap bisa melakukan eksekusi baik terhadap uang pengganti atau terhadap harta benda terpidana. Secara yuridis hal ini telah diatur di dalam angka 1 Peraturan Mahkamah Agung Nomor 5 Tahun 2014 tentang Pidana Tambahan Uang Pengganti Dalam Tindak Pidana Korupsi. Jadi meskipun surat pernyataan tidak ada dan dengan syarat terpidana belum membayar kewajibannya dalam melunasi uang pengganti dalam jangka waktu 1 bulan maka Jaksa tetap bisa melakukan eksekusi terhadap aset terpidana. Bukan harus menunggu terlebih dahulu surat pernyataan tersebut. 


\section{Akibat Hukum Terhadap Eksekusi Putusan Pidana Tambahan Pengembalian Kerugian Keuangan Negara Akibat Tindak Pidana Korupsi Tidak berhasil Dikembalikan}

Tidak tertutup kemungkinan sampai pada tahap putusan hakim telah dikeluarkan dan memiliki kekuatan hukum tetap, aset-aset yang diduga didapatkan dari hasil tindak pidana korupsi belum ditemukan. Dengan demikian tidak ada satupun aset terpidana yang bisa dilakukan penyitaan dan pelelangan.

Jadi ada 2 Akibat Hukum Terhadap Eksekusi Putusan Pidana Tambahan Pengembalian Kerugian Keuangan Negara Akibat Tindak Pidana Korupsi Tidak berhasil Dikembalikan

1. Menyerahkan kasus tersebut kepada bagian Datun (Perdata dan Tata Usaha Negara) untuk melakukan gugatan secara perdata melalui Jaksa Pengacara Negara; Hal ini sudah diatur di dalam Angka (3) huruf d Surat Edaran Kejaksaan Agung Republik Indonesia Nomor: B-779/F/Fjp/Ft/10/2015 tentang eksekusi pembayaran uang pengganti mengatakan:

"Apabila upaya telah dilakukan secara optimal ternyata tidak ditemukan aset terpidana, maka penyelesaian selanjutnya diserahkan kepada Datun untuk diupayakan melalui instrument perdata".

Hal ini dilakukan oleh Jaksa dikarenakan setelah kasus tersebut memperoleh putusan hakim yang inkracht dan dilakukan pelcakkan aset kembali ternyata ditemukan aset terpidana yang diduga didapat dari hasil tindak pidana korupsi. Oleh karena itu agar aset terdakwa tersebut dapat dilakukan penyitaan dan pelelangan dan hasilnya dimasukkan kedalam kas negara maka kasus tersebut diserahkan kepada Bagian Datun Kejaksaan. Selain ditemukan aset terpidana setelah dilakukan pelacakkan kembali.

Alasan lain kasus tersebut diserahkan ke Bagian Datun adalah terpidana tidak dapat dilakukan penuntutan dua kali dengan terpidana dan kasus yang sama (nebis in idem).

2. Menjalani hukuman subsidair sesuai dengan isi putusan hakim yang inkracht. Hal ini dilakukan oleh Jaksa dikarenakan aset terpidana yang dimaksudkan untuk membayar uang pengganti tidak ditemukan setelah dilakukan pelacakkan aset. Namun sebenarnya meskipun terpidana telah menjalani hukuman subsidair sebagai pengganti hukuman tambahan uang pengganti. Kasus tersebut sebenarnya belum bisa 
dianggap selesai. Di dalam angka (5) Surat Edaran Kejaksaan Agung Republik Indonesia Nomor: B-779/F/Fjp/Ft/10/2015 tentang eksekusi pembayaran uang pengganti mengatakan:

"Tuntasnya penanganan suatu perkara yang telah mendapatkan putusan hakim adalah apabila eksekusi secara tuntas termasuk eksekusi pemayaran uang pengganti”.

Ulasan-ulasan diatas jika dihubung-kan dengan kasus-kasus yang dicontohkan dalam karya ilmiah ini maka akibat hukum yang ditimbulkan jika keuangan negara tidak dapat dikembalikan adalah menjalani hukuman subsidair sesuai dengan isi putusan hakim yang inkracht. Hal ini dikarenakan ke tiga kasus yang dicontohkan alam karya ilmiah ini masih memasuki tahap menjalani hukuman pidana pokok dan pelacakan aset kembali. Menurut hasil wawancara yang dilakukan dengan Jaksa Fungsional mengatakan: "Jaksa telah memprediksi dari tiga terpidana hanya 2 dapat membayar uang pengganti dan 1 perkarka diatas tidak ada aset terpidana. hingga saat ini tidak ditemukan meskipun tahap pelacakkan aset dan terpidana lebih memilih untuk melakukan subsidair/pidana penjara.

\section{PENUTUP}

Berdasarkan hasil penelitian dan pembahasan serta analisis maka dapat disimpulkan hal-hal sebagai berikut :

1. Ada beberapa upaya yang dilakukan oleh Jaksa Eksekutor dalam mengem-balikan kerugian keuangan negara akibat tindak pidana korupsi, antara lain:

a. Membuat surat pernyataan pembayaran uang pengganti yang berisikan kesanggupan atau ketidaksanggupan terpidana dalam melakukan pembayaran uang pengganti.

b. Melakukan pelacakkan aset kembali untuk menemukan aset terpidana yang diduga diperoleh dari hasil tindak pidana korupsi yang tidak ditemukan oleh penyidik pada tahap sebelumnya.

2. Akibat Hukum Terhadap Eksekusi Putusan Pidana Tambahan Pengem-balian Kerugian Keuangan Negara Akibat Tindak Pidana Korupsi Tidak berhasil dikembalikan,

a. Menyerahkan kasus tersebut kepada bagian Datun (Perdata dan Tata Usaha Negara) untuk melakukan gugatan secara perdata melalui Jaksa Pengacara Negara; Hal ini sudah diatur di dalam Angka (3) huruf d Surat Edaran Kejaksaan Agung Republik Indonesia Nomor: B-779/F/Fjp/Ft/10/2015 tentang eksekusi pembayaran uang pengganti mengatakan: 
b. Menjalani hukuman subsidair sesuai dengan isi putusan hakim yang inkracht. Hal ini dilakukan oleh Jaksa dikarenakan aset terpidana yang dimaksudkan untuk membayar uang pengganti tidak ditemukan setelah dilakukan pelacakkan aset.

Ulasan-ulasan diatas jika dihubungkan dengan kasus-kasus yang dicontohkan dalam karya ilmiah ini maka akibat hukum yang ditimbulkan jika keuangan negara tidak dapat dikembalikan adalah menjalani hukuman subsidair sesuai dengan isi putusan hakim yang inkracht. Hal ini dikarenakan mneyerahkan perkara ke Datun belum pernah terjadi pada Kejaksaan Tinggi Sumatera Barat.

"Jaksa telah memprediksi dari tiga terpidana hanya 2 dapat membayar uang pengganti dan 1 Perkara diatas tidak bisa dilakukan eksekusi karna form pernyataan kesanggupan untuk membayar pidana tambahan kerugian keuangan negara hingga saat ini belum dikembalikan oleh terpidana kemudian

\section{DAFTAR PUSTAKA}

\section{Buku Taks:}

Amir Ilyas, Asas-Asas Hukum Pidana, Rangkang Education Yogyakarta \& PuKAPIndonesia, Yogyakarta, 2012.

Andi Hamzah. Hukum Acara Pidana Indonesia. Sinar Grafika. Jakarta, 2008.

------, Perbandingan Pemberantasan Korupsi di Berbagai Negara, Jakarta, Sinar Grafika, 2008.

-------, KUHP\&KUHAP. RinekaCipta, Jakarta, 2010.

Soerjono Soekanto, Metode Penelitian Hukum. UI-Press. Jakarta, 2012.

\section{Peraturan Perundang-undangan:}

Undang-undang Republik Indonesia Nomor 8 Tahun 1981 tentang Kitab Undang-Undang Hukum Acara Pidana;

Undang-undang Republik Indonesia Nomor 31 Tahun 1999 Juncto Undang-undang Republik Indonesia Nomor 20 Tahun 2001 tentang Perubahan Atas Undang-undang No 31 Tahun 1999 tentang Pemberantasan Tindak Pidana Korupsi;

Undang-undang Republik Indonesia Nomor 16 Tahun 2004 tentang Kejaksaan Republik Indonesia;

Undang-undang Republik Indonesia Nomor 8 Tahun 2010 tentang Pecegahan dan Pemberatasan Tindak Pidana Pencucian Uang:

Undang-undang Republik Indonesia Nomor 17 Tahun 2003 tentang Keuangan Negara; 
Peraturan Mahkamah Agung Nomor 5 Tahun 2014 tentang Pidana Tambahan Uang Pengganti Dalam Tindak Pidana Korupsi.

\section{Hasil Penelitian, Internet, Kamus, Dokumen:}

Berdasarkan SE-004/JA/8/1988 dan Petunjuk Teknis JAMPIDSUS Nomor: B-779/F/FT/ $10 / 2005$.

Hukum Online. Pengembalian Uang Hasil Korupsi. Diakses di www.hukumonline.com.

Komisi Pemberantasan Korupsi, Memahami Untuk Membasmi: Buku Saku Untuk Memahami Tindak Pidana Korupsi, Komisi Pemberan-tasan Korupsi, Jakarta, 2006.

Muhammad Jusuf, Kamus Hukum, Citra Umbara, Bandung, 2008.

Nashriana, Asset Recovery Dalam Tindak Pidana Korupsi : Upaya Pengembalian Kerugian Keuangan Negara, http://eprints.unsri.ac.id

Novrieza Rahmi, Siapa Berwenang Menyatakan Kerugian Keuangan Negara? SEMA Pun Tidak Mengikat, ww.m.hukumonline.com.

Riani Atika Nanda Lubis, Agus Sunaryanto kepala divisi investigasi ICW sebagaimana dikutip oleh Riani Atika Nanda Lubi, Fakultas Hukum, Universitas Indonesia, Jakarta, 2011.

Suwoto Mulyosudarmo, Kekuasaan dan Tanggung Jawab Presiden Republik Indonesia, Suatu Penelitian Segi-Segi Teoritik dan Yuridis Pertanggung jawaban Kekuasaan, Universitas Airlangga, Surabaya, 1990.

Transparancy International Indonesia. Hasil Survei CPI (Corruption Perception Index) tahun 2014. 